\title{
Effect of different fertilizer treatments on the performance of some local rice varieties under SRI (system of rice intensification) and conventional management practices at district Swat
}

\author{
Fayaz Ahmad* and Hamayoon Khan \\ Department of Agronomy, the University of Agriculture, Peshawar, Pakistan \\ *Corresponding author's email: fayaz74@gmail.com \\ Citation
}

Fayaz Ahmad and Hamayoon Khan. Effect of different fertilizer treatments on the performance of some local rice varieties under SRI (system of rice intensification) and conventional management practices at district Swat. Pure and Applied Biology. Vol. 5, Issue 1, 2016, pp37-47. http://dx.doi.org/10.19045/bspab.2016.50006

\begin{tabular}{llll}
\hline \hline Received: 03/08/2015 & Revised: 08/12/2015 & Accepted: 12/12/2015 & Online First: 14/12/2015 \\
\hline
\end{tabular}

\section{Abstract}

Different fertilizer treatments were applied to local rice varieties under SRI (system of rice intensification) against conventional management practices at ARI Mingora Swat during 20102011 using RCBD with split plot arrangement. The results show that under the SRI practices, rice varieties performed well and the plant parameters such as number of panicles plant ${ }^{-1}$, number of tillers plant ${ }^{-1}$, plant height, panicle length, grains panicle ${ }^{-1}$ biological yield, grain yield, harvest index, 1000-grain weight and plant dry weight were significantly improved under the SRI method as compared to traditional method. Combined fertilizers (NPK and Zn) enhanced rice yield significantly, which can be attributed to positive effect on yield components. Rice variety, Fakhre Malakand out performed under SRI management practices with combined application of fertilizers. It was concluded that SRI is the best management practice for rice cultivation as water availability is most likely to be a major constraint in the immediate future.

Key words: Rice; NPK \& Zn; SRI method; Tillers; Grain yield

\section{Introduction}

Rice (Oryza sativa L.) is the third biggest crop in the world after wheat (Triticum aestivum L.) and cotton (Gossypium hirsutum L.) and second major cereal crop in Pakistan. It accounts for $1.3 \%$ of Pakistan's GDP. In Pakistan rice occupies an area of 2.96 million hectares, with a total production of 6.95 million tons and an average yield of $2.35 \mathrm{t} \mathrm{ha}^{-1}$ [1]. In order to keep pace with the demand for food of the growing population, increase in rice production is the order of the day.
Managing the rice crop according to a set of principles known as the System of Rice Intensification is one of the recent developments in rice research $[2,3]$. SRI practices were started initially in Madagascar in the 1980s but are now becoming popular throughout the world. SRI practices not only enhance soil health by providing a better growing environment but also reduce the need for inputs (seeds, water, labour).

Management practices of system of rice intensification (SRI) include the following points: (1) the age of seedlings at 
transplantation is less than 15 days (two to three leaf stage); (2) seedlings are transplanted with wide spacing, and one seedling per hill; (3) water management is undertaken to maintain paddy soils in mostly aerobic condition, e.g., by small daily applications of water with no flooding, shallow water management during vegetative growth phase, active soil aeration through mechanical weeding, and application of organic matter for improving soil structure and function as well as nutrient availability [4-7].

Rice cultivation under continuously flooded conditions has been practiced for centuries [8]. However, flooded conditions create hypoxic condition, leading to a reduced soil condition (low redox potential), which cause rice to undergo adaptability in its rooting system (aerenchymal mechanism), limiting the ability of the roots to respire and ultimately slows its metabolism and growth. Furthermore, hypoxia creates low solubility of some nutrient ions and high solubility of others (Fe, Mn) [9].

In spite the difference of opinion within the academic community, SRI has been disseminated to farmers in South and Southeast Asia [10]. There is an estimate that SRI has been adopted in 750,000 ha in India, and 17,000 ha in Indonesia. A compilation of results from 11 surveys in 8 countries, including 16,000 SRI farmers, has shown, on average, a $47 \%$ yield increase, $40 \%$ water savings, $23 \%$ lower production costs, and $68 \%$ increase in farmer income, compared to conventional rice cultivation [11, 12]. Rice transplantation following the SRI method with young seedlings planted carefully and quickly puts minimum stress on the roots, planted singly to avoid root competition and planted at a vide spacing to encourage greater root and canopy growth [9].

The present proposed study aims (1) to compare the nutrient-use efficiency of the SRI system and the conventional cultivation method, (2) to estimate the nutrient requirements per unit of rice grain produced under SRI and conventional methods for producing a given grain yield, and Moreover, we want to be sure that the system being promoted has a sound scientific basis, on one hand, and is kept as simplified as possible to facilitate more widespread adoption among farmers.

\section{Materials and Methods}

The experiment was conducted at Agricultural Research Institute (North), Mingora during spring 2010 and was repeated in spring 2011, using Randomized Complete Block Design with split plot arrangement and three replications. Plot size was $4 \mathrm{~m} \times 5 \mathrm{~m}$.

Rice systems i.e., 1) SRI and 2) conventional management practices and rice varieties, i.e., 1) Fakhre Malakand, 2) Dilrosh-97, and 3) JP5 in all possible combinations were assigned to main plots whereas the fertilizer treatments were assigned to sub-plots. Fertilizer treatments included, 1) $\mathrm{T} 0=$ Control, 2) $\mathrm{T} 1=100-0-0$ $0 \mathrm{~kg} \mathrm{~N}-\mathrm{P}_{2} \mathrm{O}_{5}-\mathrm{K}_{2} \mathrm{O}-\mathrm{Zn} \mathrm{ha}{ }^{-1}$, 3) $\mathrm{T} 2=100-60-$ 0-0 kg N-P $\mathrm{P}_{5}-\mathrm{K}_{2} \mathrm{O}-\mathrm{Zn} \mathrm{ha-1}$, 4) T3 = 10060-40-0 kg N-P $\mathrm{P}_{2} \mathrm{O}_{5}-\mathrm{K}_{2} \mathrm{O}-\mathrm{Zn} \mathrm{ha}^{-1}$, and 5) T4

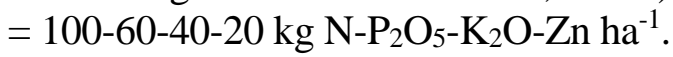

All of the phosphorous and potassium and half of the nitrogen were incorporated into the soil at the last ploughing. The remaining half was applied in two equal splits at 25-30 days and 45-55 days after transplanting, whereas zinc was applied 7-10 days after transplanting.

The data collected during the experiment were analyzed and treatment means were compared by Least Significant Difference (LSD) test [13].

\section{Results}

\section{Number of tillers plant ${ }^{-1}$}

Data regarding number of tiller $\mathrm{m}^{-2}$ are reported in Table 1. Statistical perusal of the data showed that SRI, cultivation methods, varieties and fertilizers treatments significantly affected number of tillers $\mathrm{m}^{-2}$ of rice while the effect of years was no significant. Highest number of tillers $\mathrm{m}^{-2}$ (25.19) was recorded under SRI as compared to conventional cultivation method (23.14). Among varieties highest number of tillers were counted for Fakhre 
Malakand (26.04), followed by JP5(24.25). Cultivar Dilrosh-97 resulted in lowest number of tillers $\mathrm{m}^{-2}$ (22.20). Regarding fertilizer application, the application of NPK at the rate of 100-6040-20 NPK in combination with Zn resulted in highest number of tillers followed by 100-60-40-0 NPK and Zinc $\mathrm{kg} \mathrm{ha} \mathrm{h}^{-1}$ (24.76) while lower number of tillers were counted in control plots where no amendment was practiced.

Table 1. Number of tillers of rice varieties as affected by cultivation methods and fertilizer at Mingora Swat.

\begin{tabular}{|c|c|c|c|c|}
\hline Treatments & & 2009-10 & 2010-11 & Average \\
\hline \multirow[t]{3}{*}{ Production Systems } & SRI & 25.27 & 25.12 & $25.19 \mathrm{a}$ \\
\hline & Conventional & 23.17 & 23.10 & $23.14 \mathrm{~b}$ \\
\hline & Significance level & & & \\
\hline \multirow[t]{4}{*}{ Varieties } & Fakhre malakand & 26.12 & 25.96 & $26.04 \mathrm{a}$ \\
\hline & Dilrosh-97 & 22.29 & 22.11 & $22.20 \mathrm{c}$ \\
\hline & JP-5 & 24.24 & 24.26 & $24.25 b$ \\
\hline & LSD & 0.38 & 0.36 & 0.26 \\
\hline \multicolumn{5}{|c|}{ Fertilizer treatments $\left(\mathrm{N}: \mathrm{P}_{2} \mathrm{O}_{5}: \mathrm{K}_{2} \mathrm{O}: \mathrm{Zn} \mathrm{kg} \mathrm{ha}^{-1}\right)$} \\
\hline & 0:0:0:0 & 20.84 & 20.79 & $20.81 \mathrm{e}$ \\
\hline & 100:0:0:0 & 22.90 & 22.49 & $22.70 \mathrm{~d}$ \\
\hline & 100:90:0:0 & 24.14 & 23.58 & $23.86 \mathrm{c}$ \\
\hline & 100:90:60:0 & 24.67 & 24.86 & $24.76 b$ \\
\hline & 100:90:60:20 & 28.54 & 28.83 & $28.69 \mathrm{a}$ \\
\hline & LSD $(P<0.05)$ & 0.50 & 0.47 & 0.34 \\
\hline Year $(Y)$ & & $24.22 \mathrm{a}$ & $24.11 \mathrm{a}$ & \\
\hline Interactions & \multicolumn{4}{|c|}{ Significance level } \\
\hline & Sys x Var & $\bar{N}$ & & \\
\hline & Sys x Fert & $\mathrm{N}$ & & \\
\hline & Var x Fert & $\mathrm{N}$ & & \\
\hline & $Y \times \operatorname{Var} x$ Fert & & & \\
\hline
\end{tabular}

Means of the same category followed by different latter are significantly different from one another at $5 \%$ and $1 \%$ level of probability.

* Significant at 5 level of probability.

ns $=$ non-significant

\section{Plant height}

Data regarding plant height are reported in Figure 1. Statistical analysis of the data indicated that fertilizer treatments, cultivation method and rice cultivars significantly affected plant height of rice while the effect of years was found nonsignificant. All the interactions were found non-significant. Taller plants were produced by plots where SRI production system was practiced as compared to conventional cultivation methods $(107.92 \mathrm{~cm})$. Among the varieties, highest plant height was measured for JP-5
$(118.28 \mathrm{~cm})$ followed by Fakhre Malakand $(107.61 \mathrm{~cm})$ while short stature plants were produced by Dilrosh-97 $(97.87 \mathrm{~cm})$. Application of different fertilizer also significantly affected plant height and maximum plant height was recorded in plots where NPK was applied at the rate of 100-60-40-20 kg ha ${ }^{-1}$ in combination with $\mathrm{Zn}$ followed by 100-60-40-0 NPK and Zinc application $\mathrm{kg} \mathrm{ha}^{-1}$ (110.01) whereas, control plots resulted in short statured plants $(93.89 \mathrm{~cm})$. 

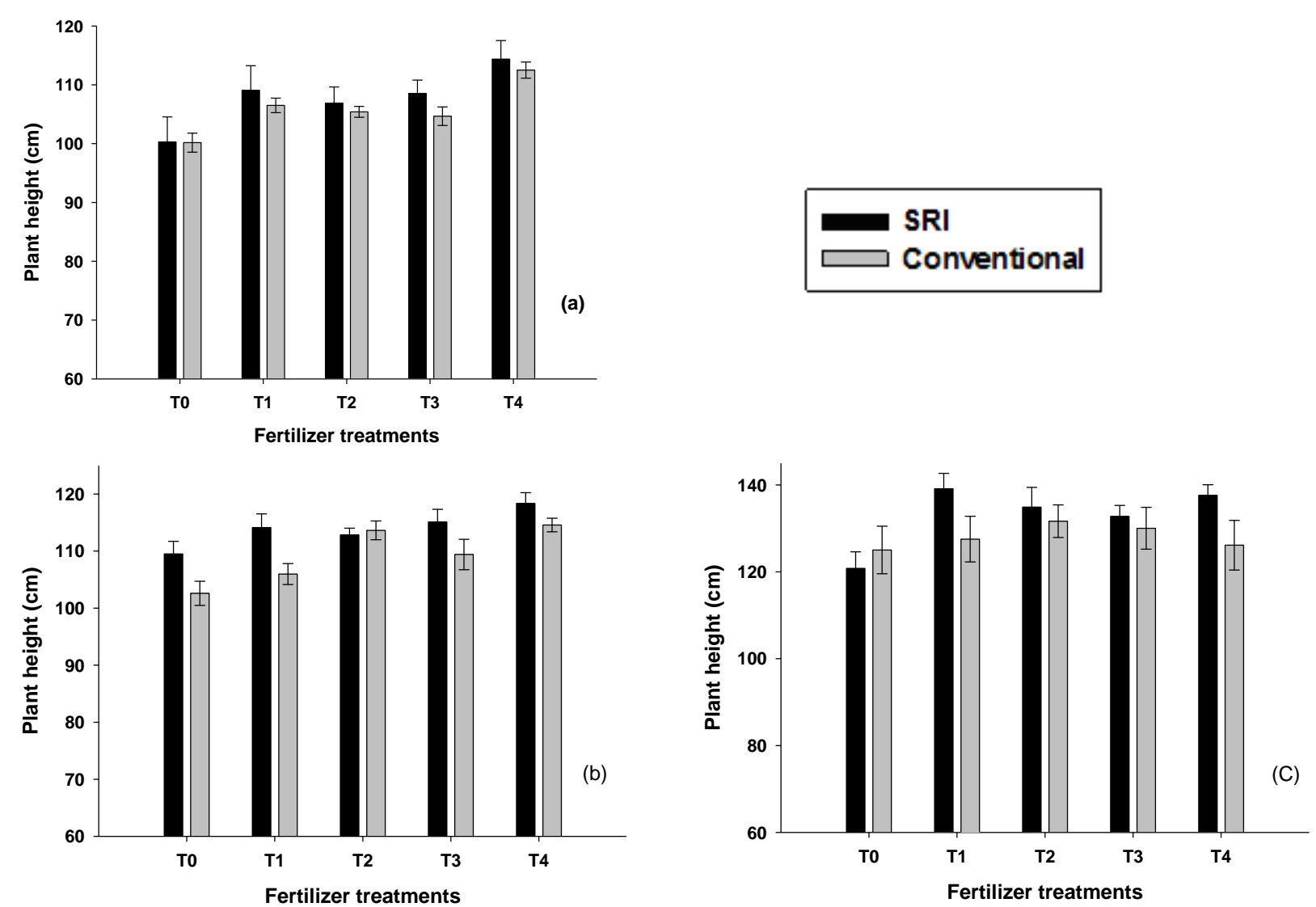

Fig. 1. Effect of different fertilizer treatments on plant height of rice varieties, a) Fakhre Malakand, b) Dilrosh-97 and c) JP-5 under conventional and SRI averaged over two years.

\section{Biological yield}

Data regarding biological yield of rice are presented in Table 2. Statistical analysis of the data indicated that biological yield of rice is significantly affected by cultivation methods, fertilizer treatments and cultivars while the effect of years as source of variation were found non-significant. All interactions were also non-significant. Higher biological yield (13.14 $\left.\mathrm{kg} \mathrm{ha}^{-1}\right)$ was recorded in plots cultivated under SRI cultivation method as compared to conventional cultivation methods (12.29 $\mathrm{kg} \mathrm{ha} \mathrm{h}^{-1}$ ). Regarding cultivars, highest biological yield was recorded for JP-5 (13.21 kg ha $\mathrm{kg}^{-1}$ followed by Fakhre Malakand cultivar $\left.\left(12.96 \mathrm{~kg} \mathrm{ha}^{-1}\right)\right)$ while Dilrosh-97 cultivar resulted in lower biological yield $\left(11.98 \quad \mathrm{~kg} \quad \mathrm{ha}^{-1}\right)$. Application of NPK and $\mathrm{Zn}$ at the rate of 100-60-40-20 resulted in higher biological yield $\mathrm{kg} \mathrm{ha}^{-1}$ (13.62 $\mathrm{kg} \mathrm{ha}^{-1}$ ) followed by NPK and $\mathrm{Zn}$ application at the rate of 10060-40-0 while control plots resulted in lower biological yield as compared to all other treatments.

Table 2. Biological yield of rice varieties under conventional and SRI averaged over two years as affected by different fertilizer treatments

\begin{tabular}{lllll}
\hline Treatments & & $\mathbf{2 0 0 9 - 1 0}$ & $\mathbf{2 0 1 0 - 1 1}$ & Average \\
\hline Cultivation methods & SRI & $13.10 \mathrm{a}$ & $13.18 \mathrm{a}$ & $13.14 \mathrm{a}$ \\
& Conventional & $12.22 \mathrm{~b}$ & $12.37 \mathrm{~b}$ & $12.29 \mathrm{~b}$ \\
\hline & Significance level & 0.033 & 0.029 & 0.021 \\
\hline Varieties & Fakhre malakand & $12.88 \mathrm{~b}$ & $13.03 \mathrm{~b}$ & $12.96 \mathrm{~b}$ \\
& Dilrosh-97 & $11.95 \mathrm{c}$ & $12.01 \mathrm{c}$ & $11.98 \mathrm{c}$
\end{tabular}




\begin{tabular}{|c|c|c|c|c|}
\hline & JP-5 & $13.14 \mathrm{a}$ & $13.27 \mathrm{a}$ & $13.21 \mathrm{a}$ \\
\hline & LSD & 0.040 & 0.036 & 0.026 \\
\hline \multicolumn{5}{|c|}{ Fertilizer treatments $\left(\mathrm{N}: \mathrm{P}_{2} \mathrm{O}_{5}: \mathrm{K}_{2} \mathrm{O}: \mathrm{Zn} \mathrm{kg} \mathrm{ha}^{-1}\right)$} \\
\hline & 0:0:0:0 & $12.05 \mathrm{e}$ & $12.18 \mathrm{e}$ & $12.12 \mathrm{e}$ \\
\hline & 100:0:0:0 & $12.23 \mathrm{~d}$ & $12.40 \mathrm{~d}$ & $12.32 \mathrm{~d}$ \\
\hline & 100:90:0:0 & $12.46 \mathrm{c}$ & $12.53 \mathrm{c}$ & $12.50 \mathrm{c}$ \\
\hline & 100:90:60:0 & $13.05 \mathrm{~b}$ & $13.02 \mathrm{~b}$ & $13.03 \mathrm{~b}$ \\
\hline & 100:90:60:20 & $13.50 \mathrm{a}$ & $13.73 \mathrm{a}$ & $13.62 \mathrm{a}$ \\
\hline & LSD $(\mathrm{P}<0.05)$ & 0.041 & 0.039 & 0.029 \\
\hline Year $(Y)$ & & $12.66 \mathrm{~b}$ & $12.77 \mathrm{a}$ & \\
\hline Interactions & \multicolumn{4}{|c|}{ Significance level } \\
\hline & Sys x Var & $* *$ & & \\
\hline & Sys $x$ Fert & $* *$ & & \\
\hline & Var $x$ Fert & $* *$ & & \\
\hline & Sys x Var x Fert & $* *$ & & \\
\hline
\end{tabular}

Grain yield

Grain yield of rice as affected by cultivation methods, cultivars, fertilizer treatments, cultivars and years as source of variation are reported in Table 3. Statistical analysis of the revealed that cultivation methods, fertilizer treatments and cultivars significantly affected grain yield of rice while the effect of years as source of variation was found nonsignificant. Higher grain yield $\left(4.82 \mathrm{t} \mathrm{ha}^{-1}\right)$ was obtained from SRI methods as compared to conventional cultivation methods (4.64t ha-1). Regarding cultivars, higher grain yield was produced by Fakhre Malakand (5.22 $\mathrm{t} \mathrm{ha}^{-1}$ ) followed by JP-5 cultivar $\left(4.99 \mathrm{t} \mathrm{ha}^{-1}\right)$ while lower grain yield was produced by Dilrosh-97 cultivar (4.33t $\left.\mathrm{ha}^{-1}\right)$. Higher grain yield was recorded from plots where NPK and Zn (5.72 ton $\mathrm{ha}^{-1}$ ) was applied at the rate of 100-60-40$20 \mathrm{~kg} \mathrm{ha}^{-1}$ followed by 100-60-40-0 NPK and Zinc application $\left(4.87 \mathrm{~kg} \mathrm{ha}^{-1}\right)$ In contrast lower grain yield was produced by control plots $\left(4.19 \mathrm{t} \mathrm{ha}^{-1}\right)$.

Table 3. Grain yield of rice varieties as affected by cultivation methods and fertilizer treatments at Mingora Swat

\begin{tabular}{|c|c|c|c|c|}
\hline \multirow{4}{*}{$\begin{array}{l}\text { Treatments } \\
\text { Cultivation methods }\end{array}$} & & 2009-10 & 2010-11 & Average \\
\hline & SRI & $5.01 \mathrm{a}$ & $4.97 \mathrm{a}$ & $4.82 \mathrm{a}$ \\
\hline & Conventional & $4.63 \mathrm{~b}$ & $4.66 \mathrm{~b}$ & $4.64 \mathrm{a}$ \\
\hline & Significance level & 0.107 & 0.248 & 0.0195 \\
\hline \multirow{4}{*}{ Varieties } & Fakhre malakand & $5.23 \mathrm{a}$ & $5.22 \mathrm{a}$ & $5.22 \mathrm{a}$ \\
\hline & Dilrosh-97 & $4.38 \mathrm{c}$ & $4.28 \mathrm{~b}$ & $4.33 \mathrm{c}$ \\
\hline & JP-5 & $4.85 \mathrm{~b}$ & $4.95 \mathrm{a}$ & $4.99 \mathrm{~b}$ \\
\hline & LSD & 0.103 & 0.303 & 0.131 \\
\hline \multicolumn{5}{|c|}{ Fertilizer treatments $\left(\mathrm{N}: \mathrm{P}_{2} \mathrm{O}_{5}: \mathrm{K}_{2} \mathrm{O}: \mathrm{Zn} \mathrm{kg} \mathrm{ha}{ }^{-1}\right)$} \\
\hline & 0:0:0:0 & $4.18 \mathrm{e}$ & $4.20 \mathrm{c}$ & $4.19 \mathrm{~d}$ \\
\hline & 100:0:0:0 & $4.55 \mathrm{~d}$ & $4.57 \mathrm{~b}$ & $4.56 \mathrm{c}$ \\
\hline & 100:90:0:0 & $4.74 \mathrm{c}$ & $4.77 \mathrm{~b}$ & $4.76 \mathrm{~b}$ \\
\hline & 100:90:60:0 & $4.92 \mathrm{~b}$ & $4.83 \mathrm{~b}$ & $4.87 \mathrm{~b}$ \\
\hline & $100: 90: 60: 20$ & $5.71 \mathrm{a}$ & $5.73 \mathrm{a}$ & $5.72 \mathrm{a}$ \\
\hline & LSD $(P<0.05)$ & 0.109 & 0.321 & 0.171 \\
\hline Year $(Y)$ & \multirow{2}{*}{\multicolumn{4}{|c|}{$\begin{array}{l}4.824 \mathrm{a} \\
\text { Significance level }\end{array}$}} \\
\hline Interactions & & & & \\
\hline
\end{tabular}




\begin{tabular}{lll}
\hline Sys $x$ Var & Ns \\
Sys x Fert & Ns \\
Var x Fert & Ns \\
Sys x Var x Fert & Ns \\
\hline
\end{tabular}

Means of the same category followed by different letters are significantly different from one another at $5 \%$ level of probability.

* Significant at 5\% level of probability.

$\mathrm{ns}=$ non-significant

\section{Harvest index}

Data regarding harvest index of rice are reported in Table 4. Statistical perusal of the data revealed that the effect of years and cultivation methods were nonsignificant while fertilizer and cultivars significantly affected harvest index of rice. All the interactions were found nonsignificant. The effect of cultivars were non-significant, however, harvest index was cultivar Fakhre Malakand (40.21\%). followed by JP-5 (37.03\%) and the minimum harvest index was noted for Dilrosh-97 (36.12\%). Regarding fertilizer, treatments higher harvest index was obtained from plots treated with 100-6040-20 NPK and Zinc $\mathrm{kg} \mathrm{ha}^{-1}$ (42\%) followed by 100-60-40-0 NPK and Zinc (38.03\%) application while lower harvest index was calculated for the control plots $(34.46 \%)$.

Table 4. Harvest Index of rice varieties as affected by cultivation methods and fertilizer treatments at Mingora Swat

\begin{tabular}{|c|c|c|c|c|}
\hline Treatments & & 2009-10 & 2010-11 & Average \\
\hline \multirow{3}{*}{ Cultivation methods } & SRI & 38.39 & 37.66 & $38.03 \mathrm{a}$ \\
\hline & Conventional & 37.51 & 37.59 & $37.55 \mathrm{a}$ \\
\hline & Significance level & 0.629 & 1.941 & 0.828 \\
\hline \multirow[t]{4}{*}{ Varieties } & Fakhre malakand & $40.46 \mathrm{a}$ & $39.96 \mathrm{a}$ & $40.21 \mathrm{a}$ \\
\hline & Dilrosh-97 & $36.60 \mathrm{~b}$ & $35.64 \mathrm{~b}$ & $36.12 \mathrm{~b}$ \\
\hline & JP-5 & $36.79 \mathrm{~b}$ & $37.27 \mathrm{~b}$ & $37.03 \mathrm{~b}$ \\
\hline & LSD & 0.770 & 2.378 & 1.015 \\
\hline \multicolumn{5}{|c|}{ Fertilizer treatments $\left(\mathrm{N}: \mathrm{P}_{2} \mathrm{O}_{5}: \mathrm{K}_{2} \mathrm{O}: \mathrm{Zn} \mathrm{kg} \mathrm{ha} \mathrm{k}^{-1}\right)$} \\
\hline & 0:0:0:0 & $34.54 \mathrm{~d}$ & $34.37 \mathrm{c}$ & $34.46 \mathrm{c}$ \\
\hline & 100:0:0:0 & $37.14 \mathrm{c}$ & $36.82 \mathrm{bc}$ & $36.98 \mathrm{~b}$ \\
\hline & 100:90:0:0 & $38.04 \mathrm{~b}$ & $38.02 \mathrm{~b}$ & $38.03 \mathrm{~b}$ \\
\hline & 100:90:60:0 & $37.71 \mathrm{bc}$ & $37.21 \mathrm{~b}$ & $37.46 \mathrm{~b}$ \\
\hline & 100:90:60:20 & $42.32 \mathrm{a}$ & $41.68 \mathrm{a}$ & $42.00 \mathrm{a}$ \\
\hline & LSD $(P<0.05)$ & 0.855 & 2.502 & 01.339 \\
\hline Year $(\mathbf{Y})$ & & $37.95 \mathrm{a}$ & $37.62 \mathrm{a}$ & \\
\hline \multirow[t]{5}{*}{ Interactions } & & Significance level & & \\
\hline & Sys x Var & $* *$ & & \\
\hline & Sys x Fert & Ns & & \\
\hline & Var $x$ Fert & Ns & & \\
\hline & Sys x Var x Fert & Ns & & \\
\hline
\end{tabular}

Means of the same category followed by different letters are significantly different from one another at $5 \%$ level of probability.

* Significant at $5 \%$ level of probability.

ns $=$ non-significan 


\section{0-Grain weight}

Data regarding thousand grain are reported in Table 5. Statistical analysis of the data revealed that the effect of years as source of variation was non-significant. The effect of fertilizer treatments, cultivars and cultivation methods were significant. All the interactions were found non-significant. Heavier grains were produced under SRI cultivation system as compared to conventional system. For varieties data revealed that higher thousand grains weight was recorded by Fakhre Malakand (32.29g) followed by JP-5 (29.95g) while minimum was noted by Dilrosh-97 (27.58g). Effect of fertilizer treatments on thousand grains weight of rice showed that heaviest grains were obtained plots treated with 100-60-4020 NPK and Zinc kg ha-1 (35.60) followed by 100-60-40-0 NPK and Zinc $\mathrm{kgha}^{-1}$ application (30.64g). Control plots resulted in lighter grains of rice.

Table 5. Thousand grain weight of rice varieties as affected by cultivation methods and fertilizer treatments at Mingora Swat

\begin{tabular}{|c|c|c|c|c|}
\hline Treatments & & 2009-10 & 2010-11 & Average \\
\hline \multirow[t]{3}{*}{ Cultivation methods } & SRI & 31.27 & 31.27 & $31.27 \mathrm{a}$ \\
\hline & Conventional & 28.56 & 28.66 & $28.61 \mathrm{~b}$ \\
\hline & Significance level & 0.33 & 0.28 & 0.22 \\
\hline \multirow[t]{4}{*}{ Varieties } & Fakhre malakand & 32.27 & 32.32 & $32.29 \mathrm{a}$ \\
\hline & Dilrosh-97 & 27.58 & 27.57 & $27.58 \mathrm{c}$ \\
\hline & JP-5 & 29.90 & 30.1 & $29.95 \mathrm{~b}$ \\
\hline & LSD & 0.41 & 0.35 & 0.27 \\
\hline \multicolumn{5}{|c|}{ Fertilizer treatments $\left(\mathrm{N}_{2} \mathrm{P}_{2} \mathrm{O}_{5}: \mathrm{K}_{2} \mathrm{O}: \mathrm{Zn} \mathrm{kg} \mathrm{ha}^{-1}\right)$} \\
\hline & 0:0:0:0 & 25.62 & 25.41 & $25.52 \mathrm{e}$ \\
\hline & 100:0:0:0 & 28.49 & 28.31 & $28.40 \mathrm{~d}$ \\
\hline & 100:60:0:0 & 29.41 & 29.68 & $29.54 \mathrm{c}$ \\
\hline & 100:60:40:0 & 30.50 & 30.78 & $30.64 \mathrm{~b}$ \\
\hline & 100:60:40:20 & 35.56 & 35.64 & $35.60 \mathrm{a}$ \\
\hline & LSD $(\mathbf{P}<0.05)$ & 0.53 & 0.45 & 0.35 \\
\hline Year $(\mathbf{Y})$ & & $29.92 \mathrm{a}$ & $29.97 \mathrm{a}$ & \\
\hline \multirow[t]{5}{*}{ Interaction } & & Significance level & & \\
\hline & Sys $x$ Var & Ns & & \\
\hline & Sys $x$ Fert & Ns & & \\
\hline & Var $x$ Fert & Ns & & \\
\hline & Sys $x$ Var x Fert & Ns & & \\
\hline
\end{tabular}

Means of the same category followed by different letters are significantly different from one another at $5 \%$ level of probability.

* Significant at $5 \%$ level of probability.

ns $=$ non-significant

Discussion

Performance of different rice varieties under SRI and Conventional management practices

The results show that under the SRI practices, rice varieties performed well and the plant parameters such as number of tillers plant ${ }^{-1}$, plant height, biological yield, grain yield, harvest index and 1000-grain weight were improved under the SRI method as compared to the traditional method. Apart from that, rice variety Fakhre Malakand gave the best results in 
comparison to other rice varieties under the SRI practices.

Careful transplantation of rice seedlings at younger stage under the SRI might have recovered quickly as a result of minor transplanting shock and improved water and plant nutrients uptake due to earlier recovery for the maintenance of quicker growth and hence higher dry matter production was observed. The results can also be explained by the fact that since the young seedlings possess high root activity and high photosynthetic activity that cause increase of leaf area and dry matter yield more than older one. These results are similar with findings of $[14,15]$. Apart from that, favourable soil conditions are created due to the alternate wetting and drying in SRI method.

Similarly, planting younger seedlings at wider spacing might have resulted in more root growth which might have penetrated deep into the soil to exploit more nutrients and water resulting in increased number of tillers, shoot and dry matter production.

Higher shoot dry matter production with transplanting of younger seedlings was also reported by [16-19] Increase in number of tillers per unit area by planting younger seedlings was observed by a number of researchers [20-22]. There were far more tillers in non-flooded plots than flooded plots [23]. Numbers of panicles were not significantly different, but the absolute value was higher for non-flooded plots than for the flooded ones. Straw yield and paddy yield were significantly higher in the non-flooded plots than flooded ones.

Many researchers reported increased grain and straw yields by planting younger seedlings than older seedlings $[17,20,22$, 24, 25, 26]. Raskin and Kende [27] reported that the maximum harvest index was recorded with transplanting younger seedlings (10- d) and the minimum value was found where transplanting was done with older seedlings (40- d).

The aerenchyma tissue in leaves and culms enables oxygen to move rapidly to the roots $[28,29]$ and sufficient oxygen leaks through the roots into flooded soils to affect biochemical activity in the rhizosphere [30, 31]. The suggestion that very wide spacing could somehow release under- exploited growth potential largely rests on the assumption that mutual shading in dense crop canopies leads to low yields.

\section{Effect of fertilizer treatments on rice}

The results show that fertilizer treatments positively affected rice attributes and under combined application of fertilizers rice yield attributes, i.e., number of panicles plant ${ }^{-1}$, number of tillers plant $^{-1}$, plant height, panicle length, grains panicle ${ }^{-1}$, biological yield, grain yield, harvest index, 1000-grain weight and plant dry weight were improved. Other workers also reported similar results. Productive tillers significantly increased with increased levels of $\mathrm{N}$ upto $120 \mathrm{~kg}$ per ha [32]. $\mathrm{P}$ play an important role in the translocation of assimilates to the panicles and also as a constituent of protoplasm. This explains the reason for the increased length of the panicle, panicle weight and number of grains per panicle [33, 34]. It was observed that application of zinc increased the number of panicles per unit area. This may be due to enhanced activity of metallo enzymes like proteinase and peptidase. Favourable effect of combined application of $\mathrm{N}$ and $\mathrm{Zn}$ on yield components might be due to the increased vigour, photosynthate accumulation and better translocation of photosynthates to the sink [35]. Application of $\mathrm{Zn}$ irrespective of $\mathrm{Zn}$ sources increased the number of panicles per unit area [36]. The yield obtained by combined application of inorganic fertilizers and $\mathrm{ZnSO}_{4}$ was significantly higher than inorganic fertilizers application indicating the synergistic effect of $\mathrm{Zn}$ and inorganic fertilizers. Nitrogen is 
known to promote tillering, improve length and width of leaves, which in turn increases the plant height and dry matter which are responsible for increase in straw yield. $\mathrm{N}$ obtained at early growth stages result in the production of more straw than grain [37].

Number of tillers was also influenced by zinc application. This might be due to high auxin production. These findings are in accordance with [38]. Combined application of nutrients and zinc caused significant improvement in number of tillers plant ${ }^{-1}$, plant height, biological yield, grain yield, harvest index and 1000-grain weight over other treatments. These findings are in accordance with the findings of [39].

As zinc is a part of various enzymes and hormones, it favoured increased synthesis of enzymes and hormones along with the metabolism of major nutrients which would in turn promote growth components. Use of increased doses of $\mathrm{ZnSO}_{4}$ increased the shoot dry matter production in wheat [40]. Similarly, in another study application of $\mathrm{Zn}$ gave the highest grain yield of rice with $41.8 \%$ yield increase over control [41].

\section{Conclusions}

The results showed that under the SRI practices, rice varieties performed well and all the plant parameters studied were improved under the SRI method as compared to the traditional method. Beside this, rice variety Fakhre Malakand gave the best results in comparison to other rice varieties under the SRI practices. Similarly, the fertilizer treatments positively affected rice attributes and under combined application of fertilizers and zinc, all the rice yield attributes were improved.

\section{Authors' contributions}

Conceived and designed the experiments: $F$ Ahmad \& $\mathrm{H}$ Khan, Performed the experiments: F Ahmad, Analyzed the data: F Ahmad Contributed reagents/ materials/ analysis tools: F Ahmad, Wrote the paper: F Ahmad.

\section{Reference}

1. Federal Bureau of Statistics (2008). Pakistan statistical year book (2008). Federal Bureau of Statistics, Statistics Division, Government of Pakistan, Islamabad, Pakistan.

2. Stoop WA, Uphoff N \& Kassam A (2002). Opportunities for improving farming system for resourse-poor farmers. Agri systems 71: 249-274.

3. Randriamiharisoa R (2002). Research results on biological nitrogen fixation with the System of Rice Intensification. In: Assessments of the System of Rice Intensification (SRI). Proceedings of an International Conference, Sanya, China, April 1-4, 2002 (Eds).

4. Thakur AK, Uphoff $\mathrm{N} \&$ Antony $\mathrm{E}$ (2010b). An assessment of physiological effects of system of rice intensification (SRI) practices compared with recommended rice cultivation practices in India. Expl Agric 46: 77-98.

5. Dobermann A (2004). A critical assessment of the System of Rice Intensification. Agri Systems 79(3): 261-281.

6. Tsujimoto $\mathrm{Y}$, Takeshi H, Hamon R, Tatsuhiko S \& Homma K (2009). Soil management: The key factors for higher productivity in the fields utilizing the system of rice intensification (SRI) in the central highland of Madagascar. Agric Systems 100(3): 61-71.

7. Thakur AK, Rath S Roychowdhury S \& Uphoff N (2010a). Comparative performance of rice with system of rice intensification (SRI) and conventional management using different plant spacing. J Agron Crop Sci 196: 146159.

8. Obermueller AJ \& Mikkelsen DS (1974). Effects of water management and soil aggregation on the growth and nutrient uptake of rice. Agro J 66: 627-632.

9. Pham ST, Thach NA, Nguyen VL \& Puckridge DW (1995). Yield trends of a long-term NPK experiment for intensive 
rice monoculture in the Mekong River Delta of Viet Nam. Field Crops Res 42: 101-109.

10. Uphoff N \& Kassam A (2009): Case Study: System of Rice Intensification, Final report Agricultural Technologies for Developing Countries STOA Project "Agric.Techl. For developing countries", 1-65. FAO, Rome.

11. Africare, Oxfarm America, WWFICRISAT Project. 2010. More rice for people, more water for planet. WWFICRISAT Project, Hyderabad, India.

12. Steel RGD \& Torrie JH (1980). Principle and procedures of statistics. A Biometrical Approch. $2^{\text {nd }}$ ed. P.862. McGraw Hill, New York, USA.

13. Assy AAA, Nigem, Zeiton OAA \& Madkour MA (1992). Effect of seedling age and hill spacing on rice. 1- Yield and yield attributes. Zagazig J agric Res 19(5): 2031-2042.

14. Parasad K, Singh R \& Singh S (1992). Effect of seedlings age and number of seedlings per hill on the yield of rice in a sodic soil. Current Agric 16: (1-2): 6770.

15. Wang SH, Cao WX, Jiang D, Dia TBY \& Zhu Y (2002). Physiological characteristics and high yield techniques with SRI rice. Asssesments of the system of Rice Intensification. 116-124.

16. Sarath PN \& Thilak B (2004). Comparison of productivity of System of Rice Intensification and conventional rice farming systems in the dry-zone region of SRI Lanka. 4th Int. Crop Sci., Conference, Brisbane, Australia,

17. Berkelaar D (2001). SRI, the System of Rice Intensification: Less Can be More. In : ECHO Development Notes (EDN) (Eds.) Martin Price and Dawn Berkelaar, ECHO, USA, Issue 70.

18. Barison J (2000). Evaluation of nutrient uptake and nutrient-use efficiency of SRI and conventional rice cultivation methods in Madagascar. In: Assessments of the System of Rice Intensification (SRI). Proceedings of an International
Conference,Sanya, China, April 1-4, 2002 (Eds.).

19. Yamah A (2002). The practice of the system of rice intensification in Sierra Leone. In: Assesment of the system of rice intensification. Proceeding of an Int. Conf., Sanya, China,April 1-4(Eds.): 103-106.

20. Sengthong V (2002). Farmer experimentation with the System of Rice Intensification in Laos. In: Assessments of the System of Rice Intensification (SRI). Proceedings of an Int. Conference, Sanya, China, April 1-4, 2002 (Eds.).

21. Mulu D (2004). Effect of seedling age, spacing and season on phyllochrons, yield and components of yield with SRI. M. Sc. Thesis, In: Report on SRI - visit to Philippines, March 19-28, 2004 (Ed.).

22. Bagayoko M, Alvey S, Neumann G \& Buerkert A (2004). Root-induced increases in soil $\mathrm{pH}$ and nutrient availability to field-grown cereals and legumes on acid sandy soils of SudanoSahelian West Africa. Plant Soil 225(12): 117-127.

23. Federal Bureau of Statistics (2009). Pakistan statistical year book (2009). Federal Bureau of Statistics, Statistics Division, Government of Pakistan, Islamabad, Pakistan.

24. Randriamiharisoa R \& Uphoff N (2002). Factorial trials evaluating the separate and combined effects of SRI practices. In : Assessments of the System of Rice Intensification (SRI). Proceedings of an Int. Conference, Sanya, China, April 1-4, (2002) (Eds.).

25. Uphoff $N$ (2005). On-farm evaluation of SRI in Tamiraparani command area, Tamil Nadu, India. In : http : // ciifad. cornell. edu/sri.

26. Armstrong W, Justin SHFW, Beckett PM \& Lythe S (1991). Root adaptation to soil waterlogging. Aquat Bot 39: 57-73.

27. Raskin I \& Kende H (1985). Mechanism of aeration in rice. Sci 228: 327-329.

28. Begg CBM, Kirk GJD, Mackenzie AF \& Neue HU (1994). Root-induced iron oxidation and $\mathrm{pH}$ changes in the 
lowland rice rhizosphere. New Phytol 128: 469-477.

29. Kirk GJD (2003). Rice root properties for internal aeration and efficient nutrient acquisition in submerged soil. New Phytol 159: 185-194.

30. Kumari MBGS, Subbaiah G, Veeraraghavaiah R \& Rao CVH (2000). Effect of plant density and nitrogen levels on growth and yield of rice. The Andhra Agric J 47(3\&4): 188-190.

31. Ishizuka, Y. 1971, Physiology of rice plant. Adv in Agronomy 23: 241-315.

32. Venkateswarlu \& Singh M (1980). Response of rice varieties to different spacings and fertility levels on yield attributes and yield. Indian. J. Agron., 25(2): 263-272.

33. Khnda C \& Dixit L (1995). Effect of zinc and nitrogen fertilization on summer rice (Oryza sativa). Indian Agron 40(4): 695-697.

34. Sarkar RK, Sasmal TK, Chakraborty AA \& Bal B (1998). Effect of micronutrient on physiological parameters in relation to yield of sunflower (Helianthus annuus L.) in rice fallow gangatic alluvial soil. Indian J of Agric Sci 68: 238-240.

35. Yoshida S (1977). Physiological consequences of altering plant types and maturity. International Rice Res Newsletter 26: 5-16.
36. Reddy MGR, Murthy VS \& Reddy PR (1984). Direct and residual effect of micronutrients on rice. The Andhra Agric J 31(3): 216-219.

37. Devasenamma V, Reddy MR \& Rajan MSS (1999). Effect of varying levels of nitrogen on growth and nitrogen uptake of rice hybrids. The Andhra Agric J 46 (1\&2): 124-125.

38. Sarwar N, Maqsood M, Wajid SA \& Anwar HM (2009). IMPACT OF NURSERY Seeding Density, Nitrogen, And Seedling Age On Yield And Yield Attributes Of Fine Rice.

39. Islam MR, Riassat TM \& JahiruddinM (1997). Direct and residual effect of S, Zn and $\mathrm{B}$ yield,nutrient uptake in a ricemustard cropping system . J Indian Soc Soil Sci 45:126-129.

40. Imran \& khan AA (2015). Effect of transplanting dates on yield and yield components of various rice genotypes in hilly area cold climatic region of khyber pakhtunlhwa-Pakistan. J Bio agric \& $h$ Care 5 (7): 1-9.

41. Imran AA, Khan F \& Ahmad (2015). Phenology of Various Rice Genotypes as Affected by Different Transplanting Dates under Cold Climatic Region of Khyber Pakhtunkhwa-Pakistan. J Environ \& E Sci 5(3): 119-122. 